assente na lei material, para o exercício da ação, se reconheça, ipso facto, ser êle portador do direito subjetivo material à negatória da paternidade. Não; para tanto seria indispensável que os fatos lhe socorressem a pretensão, sem o que, embora se lhe reconheça direito processual de ação, será esta julgada improcedente, pois que desprovido do direito subjetivo material.

11. - Cremos, desta forma, ter demonstrado que o direito processual não é totalmente independente do direito material. Este integra, através de duas das condições da ação, o título do direito de agir.

Proclamamos e reconhecemos a distinção entre a relação material e a relação processual, e afirmamos que, ao situarmos aquelas condições da ação no direito objetivo material, não estamos, com isto, exigindo que o autor seja efetivamente titular do direito subjetivo material, nem, sequer, que haja qualquer relação jurídica material entre as partes, pois que esta se define através da análise da premissa menor do juízo; ao passo que as condições da ação consistem, exclusivamente, na verificação de que a lei material acolhe, em tese, o pedido, e admite, não como real, mas simplesmente como possível, a titularidade entre as partes, situando-se, assim, tão só, no âmbito da premissa maior.

Esta vinculação do direito processual à lei material, sem qualquer cogitação de que o autor seja efetivamente titular do direito subjetivo que alega, condiz, a nosso ver, com a verdadeira posição instrumental do processo. Jamais poderemos esquecer que o processo é um meio de realização do direito e da justiça material.

Já é tempo de nós, cultores do direito processual, ao invés de proclamarmos uma independência absoluta, que não se concilia com a natureza de nossa ciência, lhe reconhecermos, ao contrário, com humildade, o verdadeiro papel e a legítima função - de meio voltado para o nobre fim de definir o direito material in concreto.

Só desta forma dar-lhe-emos a alta dignidade que ela possui no universo das ciências jurídicas.

\section{ORAÇÃO DE PARANINFO *}

\section{OSWALDO CAMINHA}

\author{
Catedrático de Direito Civil
}

A esta tribuna venho trazido pelo braço de uma mocidade radiosa e prazenteira, para o cumprimento de um dever indeclinável que ela mesmo me impôs, bem que honroso e grato ao coração.

Eu não poderia deixar de atender a um pregão irresistível dos moços que hoje dos bancos acadêmicos se despedem, acreditados solenemente por esta Faculdade para enfrentarem lá fora, nas lidas da vida profissional, as refregas contingentes pela salvaguarda ardorosa do Direito.

Sem contraste com o indizivel reconhecimento pela deferência amável do convite, eu não poderia, nem me seria perdoado, acomodar-me a excusas, de certo modo aturdido, embora, pela consciência de minha humildade, entremeio das conjeturas sôbre a razão por que teria eu sido indicado para paraninfar êste pugilo garboso e galhardo de jovens no presente ato em que venturosamente recebem o grau de bachareis em ciências jurídicas e sociais.

Só pude dar tento de que aí teria prevalecido a circunstância de, ao lado dos eméritos professores que, com minha modesta aju$\mathrm{da}$, prepararam os diplomandos de hoje para êste instante supremo de seu curso acadêmico, haver sido eu aquêle a quem, pelo programa da cadeira, tinha de se proporcionar mais dilatado tempo de convívio cultural com êstes.

Os quatro longos anos, com efeito, de continuidade nessa necessária comunhão de inteligência e nobres sentimentos, entre a experiência de minha velhice e a esmerada juventude estudantil que, vis-a-vis desta cátedra, nesse largo estágio, comigo se defrontou, foram, creio eu, a razão de se me deparar, a mim também, a ventura de lhe grangear a estima, fortalecida, porém, para o meu lado, pela maioridade do tempo na ininterrupta sucessão dês- 
ses quatro anos de trabalho contínuo e esperanças alviçareiras.

Afortunada quadra avançada esta da minha vida, quando as sim alentada pela estima desinteressada da mocidade, da mocidade que lhe esteve perto durante quase todo um curso superior, valorizando-lhe o amor à vida que ainda lhe resta, sublimando-lhe; mesmo, a afanosa existência com as irradiações daquela revigorante aura juvenil e as louçanias daquêle trato quase filial, que sempre pareceram, ao velho mestre, ter o efeito assim como o da magia sob a qual o suave ambiente do próprio lar se lhe ampliasse neste ameno convívio com seus discípulos.

Nesta altura de minhas demoradas e ásperas mas gratas peregrinagens pelas searas e veredas do Direito, no Ministério Público, na Magistratura, na Advocacia e no Magistério, ante as alternativas das alegrias e dos desenganos do mundo, nem poderia eu colhêr mercê mais expressiva, do que a dessa estima para minha longa vida pública, de tantos dissabores e contentamentos entremeada. Tanto mais quanto o seu maior significado e a sua virtude mais íntima e mais forte são, no meu sentir comovido, aquilo que agora em mim mais ainda aviva e rejuvenesce a compreensão do poder e excelência da amizade, alto sentimento que Emerson, filósofo e poeta, tanto exalçava nos que lh'o votavam, confessando que êstes "enchiam o mundo para êle de novas e nobres profun. dezas e alargavam o sentido de todos os seus pensamentos, como um remédio da vida e um bem da imortalidade".

A propósito, quero neste lance assinalar que aqui muito me aprouve em vários ensejos observar no seio dessa mesma juventude êsse sentimento sempre se cultivou, no afeto e respeito de uns pelos outros, como maravilhoso vínculo de união estudantil, por diversas e harmoniosas formas manifestada, inclusive nas assembléias gremiais, celebradas para o exame de assuntos de interêsse geral, universitário e social e, às vêzes, até mesmo de cunho altamente cívico, a exemplo do que nos conta a história política do país, notadamente da época da campanha abolicionista ou de propaganda republicana, exaltadas ambas pela mocidade ardorosa das escolas daquêles tempos.

Oxalá, aos novos combatentes do Direito, bafeje sempre, para frutificar pelos dias incertos do porvir, a lembrança, nostálgica, porém fagueira, dêsse convívio benfazejo e dêsse elo de estima inolvidável, que eu almejo se irradie e se multiplique nos registros de grandes e novas afeições, em que se harmonizem, completandose: a estima com o respeito mútuo; com a altivez que dignifica, a mansidão que desarma e vence; o respeito pelas conviccões alheias, com o resguardo das próprias; com as legítimas aspirações individuais, o espírito cavalheiresco de renúncias generosas; as justas ambições pessoais, com a caridade que beneficia, transige e perdoa; com seus interêsses particulares, o sentimento de solidariedade hu- mana; a discrição prudente, com as expansões benéficas do pensamento; a circunspecção, com as inofensivas, alegres e sutis malícias do bom humor; com o amor próprio, a capacidade de sacrifício pelo próximo; o apêgo às coisas terrenas, com o amor a Deus.

Com êste gênio, o gênio do bem, aliado ao aperfeiçoamento crescente da cultura e à devoção pelo trabalho, poderão, então, com simpatia e confiança, com entusiasmo e decisão, com fé, em suma, mesmo por entre as procelas eventuais da existência, corajosamente enfrentar o mundo que, aleatório, mas imenso e opulento em possibilidades e ofertas, em frente agora se lhes abre.

Numen tutelar confortativo nas vicissitudes do presente e consolador nos agravos do passado, sua fé aí ainda inundará de luz suas legítimas esperanças em abundantes dádivas do futuro.

$\mathrm{E}$ assim como em rígido bordão se arrima o peregrino por entre os acidentes e incertezas dos caminhos, assim também nela seu ânimo se abrigue dos desgostos e desenganos do mundo, talvez mais frequentes nos misteres da vida pública, nas controvérsias da política e sobretudo, quiçá, em episódios dos embates partidários.

Melhor fôra, em verdade, e mais excelente, que, em meio às amarguras acaso sofridas nessas pugnas, jamais os espíritos jovens se entibiassem e nelas nunca em desalentos e recuos se trocasse a perseverança varonil no zêlo e ardor patriótico com que antes porventura hajam na liça propugnado pelo ideal democrático de uma grande pátria de homens livres, engrandecida no conceito das nações, cada vez mais feliz pela cultura crescente de sua gente, pela austeridade e pujança de sua política e, assim, pela integridade e abastanca de seu viver.

Pena é, porém, que, por atritos e extravios no desenrolar dês. ses certames, degenerem êles, por vêzes, com perturbação da tran quilidade pública e com risco até para a paz social, no choque de ambicões pessoais descontroladas e de paixões exacerbadas, obscurecendo a compreensão dos mais caros e lídimos deveres de civismo e comprometendo aquêles superiores interêsses de Estado que con:tituem a razão suprema e fundamental dêsses pleitos.

De modo que, ao jovem cultor do direito, quando confrangido pelas cenas dêsse quadro ou refratário à participação ativa nessas pugnas, apresentam-se as letras jurídicas tanto na abençoada solidão de profunda atividade interior, quanto nos sacerdócios da magistratura, da advocacia, do magistério ou de outra forma, falada ou escrita, de evangelização do Direito - um revigorante e purificador refúgio a êsses e outros dissabores e campo imedivel de expansão de outros pendores do espírito, bafejado por nobres e altruísticos ideais.

Constituem imenso e inexgotável manancial de cultura exposto a propiciar mesmo o sucesso, porventura percuciente, de grandes 
jornadas culturais em prol do bom direito, rumo a outros grandiosos benefícios à Comunidade.

Nem é outro, nisso, o destino da crítica construtiva ou reno. vadora, a finalidade suprema, em suma, do mister do intérprete seja êle o jurista glosador para explicar ou sugerir, ou o juíz para decisivamente proclamar e aplicar, ou o próprio legislador para, inspirado nas conclusões dessas e outras fontes de interpretação, discutir e elaborar afinal novas fórmulas de expressão dêsse mesmo direito.

Em verdade, nesse edificante labor, o intérprete moderno que se emancipa do fetichismo da lei, que se isenta de superstições legais, de teorias materialistas, e das ideologias totalitárias para as quais só o Estado soberano é órgão ou fonte de elaboração do direito, assume a alta missão de investigar o direito justo, o direito jurídico, mediante o exame da estrutura e do sentido e conteúdo do direito legal, em face dos imperativos sociais

Impõe-se-lhe, para isso, a irremovível condição de perscrutar, na natureza objetiva das coisas, os elementos de solução, que, de acôrdo com as realidades sociais, com as novas exigências e condicões da vida, possam imprimir ao têxto uma vida atualizada, isto é, justificável aplicabilidade atual, ou que, na hipótese de impraticabilidade disto, sugiram expressões novas de ordenamento.

Não obstante, porém, essa dependência de fatores sociais a que corresponde o caráter cambiante do direito positivo, o trabalho do intérprete não pode deixar de por vêzes se condicionar também à invocação e predomínio de um ou outro dentre os princípios essenciais de Direito Natural que atua sôbre o direito positivo por dois lados diferentes, levando-o a sentir simultâneamente, comì assinala Josserand: de uma parte, "o império de necessidades eternas e constantes, das verdades primeiras que constituem o seu contingente apriorístico e têm o valor de dogmas imutáveis a que nenhum organismo físico nem social não poderá subtrair-se jamais", e, de outro lado, a influência de "aspirações múltiplas e variáveis ate um ideal evolutivo", as necessidades práticas, o influxo das conveniências sociais, ou, como diriam os próprios neo-tomistas, a necessidade de acompanhar as determinações da experiência.

Envolvido, embora, em dado lance de sua história, por densas sombras provocadas por uma filosofia hostil, por um negativismo às vêzes até agressivo, êsse direito, superior à vontade do legislador e a cuja orientação e direção tem o direito positivo de se submeter, vem há mais de meio século, por um fenômeno de providencial reação das consciências, despertadas por copiosa e ardente literaratura filosófica, ressurgindo do eclipse, com sua brilhante e incisiva readaptação no pensamento jurídico contemporâneo, numa fase a que Le Fur chama "o período científico da sua história".

Para decisiva e vantajosa compensação, assim, das vicissitudes do século XVIII e XIX, vêm significando as proclamações do renascimento vitorioso do Direito Natural um movimento de volta dêste ao prestígio da época de seu apogeu, sob a influência de uma re. novada e cada vez mais aclamada filosofia, enriquecida constantemente por um número crescente de prosélitos e paladinos talentosos, no livro, na tribuna, nos institutos de filosofia de direito e de sociologia jurídica, e até nas conferências e congressos internacionais, e impregnada, como diz Darcy Azambuja, das idéias e princípios que inspiraram os grandes sistemas de Sto. Tomaz de Aquino, Sto. Agostinho e outros luzeiros da Igreja e da filosofia.

Mas, ao mesmo tempo que a prestigiosa literatura dos filósofos e dos publicistas tem, assim, a seu crédito o rejuvenescimento do direito natural, os juristas igualmente, sobretudo na França, e notadamente todos os civilistas, como mostram Dabin e Ripert, tecem hosanas à existência dêsse verdadeiro modêlo das leis civis e cujos princípios essenciais não podem estas desvirtuar sem ruina ou abalos nos fundamentos institucionais da sociedade civil

E' que êsses princípios, que presidem à constituição de todo direito positivo, sendo-lhe preexistentes, por congênitos na criatura humana e manifestados quando descobertos pouco a pouco pela civilizacão, não são criação do homem, senão natural revelação à consciência individual e social do homem, do qual é construção apenas a forma, a expressão, o registro dessa revelação no direito escrito, em regra por necessidade de ficar assegurada pela sanção a sua fiel observância.

Daí o se nos depararem êles articulados a cada passo no conjunto das regras legais, integrando com estas o conteúdo todo do próprio direito positivo.

Nem por isso sofrem perda, antes ganham a consagração da sua índole, do seu caráter originário, primordial, de princípio do direito natural "informativo das leis vigentes, ou porque estas os formulam assim expressamente, ou porque os pressupõem como máximas implícitas ou subentendidas, sem as quais muitas disposicões particulares ficariam sem sentido", como assevera Del Vecchio.

Quando, ao invés disso, a lei lhes é adversa, violando-os, a resistência é lícita, a solução deve pender para a sua prevalência, mormente considerando que êles são não só "uma moral traçada ao legislador para lhes inspirar as normas por êle editadas", mas constituem uma ordem juridica distinta, que domina, que "enerva, no dizer de Renard, o direito positivo inteiro".

A expressão em versículo constitucional do princípio omitido ou frontalmente violado pela lei, ou sua dedução do âmago da estrutura constitucional, suaviza, sem dúvida, consideràvelmente, o papel do intérprete, a função do juíz. Cinge-se esta ai ao dever de julgar inconstitucional a lei. 
Em hipótese contrária, porém, ressente-se de maior gravidade e sobremodo alteia-se a missão do juíz, que se situará então entre o direito legal e o direito jurídico, com a tarefa de decidir da sorte de uma lei a ser considerada injusta por contrária ao direito.

Em certas conjunturas, nos encargos relevantes e difíceis do magistrado, impõe-se assim o imperativo de tomar uma solucão humana e heroica, por vêzes modelar e percuciente e quiçá glorificadora pela irradiação, por ventura, no mundo jurídico, pela sua propagação de profunda penetração social e política.

Em emergências tais, pôsto deva o intérprete recorrer primeiro aos meios de reparação fornecidos pelo direito positivo, le gítima será, contudo, a prevalência do direito não escrito, como incisivamente afirma Del Vecchio, "quando for sobejamente flagrante o contraste entre as normas escritas e as exigências imprescritíveis da natureza humana".

Evidentemente é essa solução um imperativo de justiça para o caso em que a lei aberre dos princípios que encouraçam os valores morais indispensáveis à coexistência humana.

Onde, segundo o sistema de Sto. Tomaz de Aquino, não há "uma perfeita conformidade da lei humana com a lei natural", onde "as leis humanas são injustas, não se lhes deve obediência", ressalvados, diria êle, os casos de desordem provocada pela resistência.

De qualquer modo, os princípios de direito natural são a expressão genérica, fundamental, de um direito em cuja essência se traduz e se fixa, por determinação de um sentimento inato, por urm imperativo irremovível e inolvidável da natureza humana, a noção do justo e do injusto. O próprio Leon Duguit, pôsto afirmar-se o caráter infinitamente variável e cambiante dessa nocão, concedia, contudo, que o "sentimento do justo e do injusto é um elemento permanente da natureza humana, verificado em tôdas as épocas e em todos os graus de civilização, na alma de todos os homens, desde os mais sábios até aos mais incultos".

São máximas destinadas a impregnar, a fecundar todo o direito positivo, constituindo, na estrutura ou ao lado dêste e paralelamente, a êle, um obstáculo, pelo menos uma advertência altissonante e permanente contra os injustos excessos dos poderes públicos, uma reacão perseverante e clamante contra as concepç̃es brutais do direito, como aquelas do extinto nacional socialismo; contra a "concepcão de um direito baseado, como diz Ripert, sôbre a fôrça do poder”, e um protesto de tôda a hora, não só especulativo, mas incisivo e irrespondível, humano e bradante, ao totalitarismo revolucionário de tôdas as ideologias materialistas, perigosas ao harmonioso convívio social e à dignidade da pessoa humana.

De entre tais máximas, uma das mais ameaçadas por aquêles excessos ou concepções e por estas ideologias, é um princípio en- gastado como um dogma, um axioma, na consciência jurídica dos povos de civilização sobretudo cristã e consagrado na maioria das legislações das nações cultas, qual seja o princípio da irretroatividade das leis, cuja história entre nós talvez ilustre a afirmação de sua relevância, revelada ainda mesmo nos contrastes de certo episódio.

Erigido, com efeito, no direito brasileiro, desde o Império, em dogma constitucional, sôbre êle, todavia, inteiramente silenciou apenas a carta política de 1937 , em consonância, por certo, com as conveniências eventuais do regimen então pôsto à prova no país.

Por isso, nesse entrementes, o princípio deixou de ser norma constitucional para o legislador e resultou reduzido à categoria de mero preceito de orientação para o juíz, na apreciação da eficácia das leis no tempo, conforme os têrmos da lei de Intr. ao Cod. Civil, que fixava o limite da retroatividade no direito adquirido, ato jurídico perfeito e coisa julgada.

A seguir, entretanto, foi ela substituida, em 1942, por outra lei de introdução, entre cujas disposições, a mais importante e audaciosa, por constituir uma ameaça para a infinidade de relacões de direito privado, foi a que - além de alterar aquêles têrmos da anterior, trocando a menção do direito adquirido e da coisa julgada na de "situações jurídicas definitivamente constituídas", aliás adotada alhures e em certa doutrina - estabeleceu também, e de modo contraditório, que tais situações ficariam a salvo do efeito retroativo de qualquer norma legal nova, sòmente quando esta mesma não prescrevesse expressamente a sua própria retroação a essas situações e ao ato jurídico perfeito.

Muitos decretos-leis a isso sucessivamente se seguiram com cláusulas expressa nesse sentido, algumas com fixação, no passado, da data ou período alcançado pela retroação expressa.

Destarte, entrou o princípio da irretroatividade, com inquietação geral, no mundo dos negócios privados, a ser pôsto em risco permanente, à mercê do arbítrio do legislador exercido por vêzes, com efeito, em sentido sucessivamente contraditório sôbre a mesma matéria.

Ficou isso como um exemplo histórico da influência do fator político sôbre a elaboracão e transformacão das leis civis, mesmo nas democracias, como afirma Ripert, o qual ilustra esta afirmativa com as cambiantes a que a política alternadamente submeteu a natural indissolubilidade do vínculo matrimonial na França: "A Revolução estabeleceu o divórcio por amor da liberdade e desejo de laicismo; mas a Restauração o suprimiu para agradar à Igreja; e a Terceira República restabeleceu-o; talvez por motivo contrário. Ainda há pouco, de uma República Sul Americana nos vêm notí: cias da influência dêsse fator político para a votação apressada 
de uma lei sôbre o divórcio, contra o pensamento da igreja católica, com a qual a política do Governo está ali em divergência".

Não importa que no Brasil o interêsse político tenha visado segundo se tem dito alhures, um fim de justiça reparadora para a eventualidade de casos especiais de relaçốes privadas a serem oportunamente reexaminadas retroativamente pelo arbítrio prudente do legislador.

Mas, é evidente que confiar isso à aleatoriedade dos duvidosos acertos retroativos do órgão legiferante, vale negar segurança à estabilidade daquelas relações e criar-lhes intranquilidade permanente, sobrepondo ao império de um princípio geral, que é regra moral legislativa, o predomínio dêsse arbítrio, nem sempre prudente e sábio e ordinàriamente perigoso e inquietante, quaisquer que sejam os intuitos de justiça que o hajam porventura autorizado.

Posteriormente, porém, foi o inviolável princípio recuperado de seu ostracismo; trazido do banimento que sofrera naquêle período crítico; restabelecido entre as condições de vida de nosso direito privado; aviventado nos alicerces da construção dêste mesmo direito; rearticulado, em suma, sem condições nem ressalvas expressas, entre os cânones constitucionais da república democrática brasileira, com aquêles traços seculares com que sempre se experimentou entre nós, sem contrariedade nem abalos, antes como constante penhor à estabilidade e, portanto, como fomento ao progresso do jôgo infinito das convenções privadas.

A modificação que por aquêle jeito o abalara, foi uma nuvem ameaçadora que passou, deixando, não obstante, rastos indeléveis e aniquiladores em relações de direito privado; foi um episódio novelesco e dramático de sua entrosagem em nosso direito escrito, ocorrido em meio a uma crise política.

Pôsto o incidente haja assim virado fato dos dias idos, não é demais que o registremos como advertência pela defesa sempre vigilante do já agora novamente postulado constitucional, reprodução de um princípio de direito natural, no sentir de Josserand e outros, e viga posta como condicão de solidez e vitalidade em tôda armadura jurídica reguladora das relacões de ordem privada.

A reforma que cometera ao arbítrio do legislador a apreciação da conveniência e oportunidade de elaborar leis expressamente retroativas, foi, a meu ver, o efeito mais profundo da influência daquêle momento anormal da nossa história política sôbre o direito privado pátrio.

Em compensação, dos demais atos legislativos discricionàriamente expedidos naquêle ínterim, assim como dos praticados, aliás constitucionalmente, em períodos normais porém posteriores também à nossa codificação civil; de todos êles só se pode dizer que não vieram em nada colidir com os sistemas e instituições do direito civil nacional.
Exprime-se, realmente, essa Nova Legislação numa coleção de leis oportunas que, não obstante certos erros, vieram enriquecer, fecundar de novas provisões o nosso direito civil anteriormente codificado, atendendo, em grande parte, às condições sociais posteriores a êle, aos reclamos da atualidade, provindos de interêsses de ordem familiar, moral, e sobretudo econômica e social.

Basta, em abono dêsse asserto, recordar o advento, por exemplo, de:

A - No Direito de Família, leis justificadas pela finalidade de regular: 1) as condicỗes de eficácia civil do casamento religioso, hoje amparado pela Constituição, em atenção às aspirações sobretudo cristãs da grande maioria do povo brasileiro; 2) a organização e proteção da Família, com disposições provendo sôbre o cumprimento de obrigações alimentícias, sôbre mútuos para casamento, sôbre educação escolar e até sôbre recreacão gratuita de famílias pobres, abonos familiares, amparo a famílias em situação de miséria, o bem da família; 3 ) a exigência de prévia formalidade conciliatória dos cônjuges nas ações de desquite, com o objetivo de salvaguardar a concórdia conjugal, essencial à paz da família; 4) ampliacão dos casos de filiacão ilegítima suscetível de reconhecimento; 5) uma melhor assistência e proteção à pessoa e bens dos menores, sobretudo abandonados; 6) vigilância e amparo à pessoa e bens dos psicopatas, assunto de relevante importância profilática e social;

B - No direito das obrigações, além da lei de 1919 dispondo sôbre as obrigações resultantes de acidentes do trabalho, as que decretam: 1) medidas severas de proscricão da usura, ostensiva ou dissimulada - grande passo experimentado, já por imperativo constitucional, em proteção das vítimas do capitalismo insaciável 2) as condiçôes de renovação dos contratos de locação de imóvei destinados a fins comerciais; 3) a rescisão das locações de prédios a militares e civís dispensados ou sujeitos à redução de vencimentos, atento o pensamento de equidade ajustado sem dúvida à fôrca maior dessa dispensa ou redução; 4) o provimento da situação, em geral, do inquilinato urbano, motivada, como em todo o mundo, pela sabida e persistente crise residencial; 5) as medidas de salvaguarda dos legítimos interêsses dos compromissários compradores contra o eventual arrependimento e má-fé do compromissário vendedor nos contratos de compromissos de compra e venda de imóveis;

C - No direito das coisas: 1) os importantíssimos códigos de minas, de caca e pesca, de águas, de proteção à lavoura e às florestas do país; 2) outras leis, como estas, também restritivas da propriedade privada, tais como a que amplia o conceito de utilidade pública para a desapropriação; 3) novas normas sôbre n penhor rural e o de máquinas para indústria; 4) outras, sôbre o 
aforamento de terrenos de marinha, sôbre concessão de terras devolutas; 5) a instituição da hipoteca aeronáutica, à semelhança da naval; 6) da caução de crédito hipotecário ou pignoratício; 7) e uma notável lei erigindo à categoria de direito real o direito do compromissário comprador, para preservar êsse seu direito contra qualquer ato do promitente vendedor, traslativo de domínio do imóvel compromissado; além de,

D - No Direito das Sucessões, a limitação até o $4^{\circ}$ grau em linha colateral da ordem da vocação hereditária, atento o presumido enfraquecimento gradativo do elo afetivo nessa linha de parentesco.

Além dessas e muitas outras leis posteriores ao Código, merece aqui também salientado o regulamento dos Registros Públicos, de 1939, apreciável evolução, neste particular, do direito anterior, desde sua origem na velha e notável legislação imperial e na também sábia coleção de decretos do govêrno provisório de 1889 .

De todos êsses instrumentos legislativos, sobressaem em quantidade e projeção, os que se articulam no Direito das Obrigações e no Direito das Coisas.

São expressões, é evidente, de índole patrimonial, destinadas a prover, ora a necessidades críticas decorrentes de contingente depressão econômica, ora a conveniências ditadas pelo interêsse, por exemplo, de fomentar e dirigir, com os modernos recursos técnicos, o desenvolvimento de nossas riquezas naturais, disciplinando-lhes a exploração, a industrialização, a apropriação individual, em combinação com as inspiraçốes da utilidade pública.

Mas, de entre êsses ordenamentos, dois se apresentam motivados direta e imediatamente por fenômenos de verdadeira crise, crise de habitação urbana.

São: as sucessivas leis emergentes e transitórias, mas sempre prorrogadas, denominadas leis do inquilinato, e a que sistematizou, ante o desequilibrio resultante já da primeira guerra mundial, uma nova modalidade do condomínio imóvel, antes adotado em outras legislações - o condomínio do edifício de apartamentos pertencentes a diferentes proprietários.

Um outro conjunto de numerosas e importantíssimas normas legais entrementes construido e incorporado ao seio do nosso direito positivo, foi a providencial legislação que, disciplinando as relações individuais e coletivas de trabalho nela previstas, instituiu, entre nós, outro grande ramo do direito, um direito novo, o novo direito do trabalho.

Pôsto participe também do Direito Público, essa legislação regula, contudo, relações de Direito Privado por excelência, originadas de verdadeiras locações de serviços, a respeito das quais - por desdobradas em várias modalidades ou espécies, de categorias aparte e por virem disciplinadas ao lado da solução legal de vários outros problemas sociais - o Direito Comum lhe cedeu o passo, embora suprindo-lhe as lacunas através do Código Civil, coms fonte subsidiária.

Valha por isto a referência aqui feita ao novo e pujante direito, além de pela homenagem que merece como abundante repositório contra o mal, condenado pelo direito natural, de exploração do homem pelo homem e igualmente como medida preventiva contra crises porventura possíveis ou fomentadas nas relações de concórdia e solidariedade entre as numerosas classes locadoras e a poderosa grei locatária de seu trabalho.

E' claro, porém, e é de todos sabido, que nenhuma das criações aqui apontadas, surgiu de quaisquer convulsões sociais, de agitações ideológicas, de conturbações políticas, de promessas programáticas de partidos, senão apenas do encontro com novas realidades econômicas e sociais evidentes; com situação de injustiças clamantes; com as sugestões do útil em relação à família e ao estado e potencialidade de nossas riquezas naturais.

Nenhuma dessas novas leis, com efeito, contrasta revolucionàriamente com qualquer princípio ou doutrina construtiva, inteiramente ajeitável porventura, às realidades econômicas e sociais do século presente, até certo ponto alérgicas, aliás (digamos assim), à crença exclusiva e essencialmente individualista do direito privado das democracias da primeira metade do século passado, principalmente em relação ao direito de propriedade e, no campo do direito das obrigações, à teoria dos contratos.

$E^{\prime}$ que, dentre elas, as que se prendem à teoria dos contratos foram elaboradas com a preocupação, ou melhor, sob a influência irresistível, agora mais oportuna do que nunca, do princípio da solidariedade social que, desde a segunda metade do século XIX vem tendendo a prevalecer nas fases estipulativa e vinculatória obrigacional das convenções, isto é, sôbre o princípio da autonomia da vontade e sôbre o da obrigatoriedade, não obstante constituirem ambos a essência, a alma, a vida das relações contratuais.

A compreensão cada vez mais viva "das vantagens da solidariedade que aproxima os homens em todos os domínios da atividade", como diz Maximiliano, não podia deixar de acolher e prestigiar a política legislativa que imprimiu, mais ampla e abertamente, mediante aquêles e outros ordenamentos, o cunho de um imperativo legal ao princípio de solidariedade social, para a vida e a evolução das convenções privadas.

Veio, assim, êste princípio, por sua vez também, ampliar mais ainda a área de influência e dominação de um outro princípio, que igualmente dirige ou condiciona o direito contratual princípio da supremacia da ordem pública.

Outros são os aspectos, é verdade, sob que êste já atuava com papel de restringir a autonomia da vontade e às vêzes até 
mesmo modificar a fôrça obrigatória das convenç̃es particulares.

Mas intervem agora, sem dúvida, pelo prisma também da solidariedade social, nesses dois lances da vida do vínculo obrigacional.

Foi certamente, não será demasia insistir; foi evidentemente sob a inspiração do princípio da solidariedade entre os homens, aliás já ressaltânte de várias disposições de cunho coativo do Código Civil, que se elaboraram muitas das novas normas em apreço, algumas, por isso, restritivas da liberdade contratual e outras, modificativas, suavizadoras da obrigatoriedade dos contratos.

Tôdas elas, veiculando êsse pensamento, incorporaram-se ao nosso direito positivo plenamente justificadas por uma causa ocasional, de repercussão geral, e consistente na depressão econômica mundial, reinante desde a primeira grande guerra, que veio situar e desajustar o mundo das convenções privadas diante de conjunturas imprevistas e imprevisiveis no momento da estipulação.

Essa crise econômica, além disso, teve a consequência de, por outro lado, mais ainda justificar, em seguida, já ao tempo do segundo conflito internacional e sob a inspiração dêsse mesmo princípio de solidariedade social, a propensão, cada vez mais generalizada, para a revisão das obrigações acaso transmudadas, por circunstâncias ulteriores imprevisiveis, em ônus sobremodo injusto e ruinoso para o devedor.

Enfileiram-se entre as leis que entre nós se decretaram obedecendo a essa inclinação, as que versam sôbre a moratória e o reajustamento econômico e as relativas à usura, ao inquilinato, à renovaç̃o do arrendamento de prédios para fim comercial ou industrial, à locacãa residencial a funcionário civil ou militar removido ou sujeito a diminuição de vencimentos, e muitas outras mais.

$\mathrm{O}$ que se vê aí é a acomodação, em leis especiais, coativas, da doutrina da revisão, moderna, é certo, na fixação do conceito e delineamento ostensivo, mas já manifestada, em essência, através de antiga idéia sôbre a injustiça da exequibilidade de uma obrigação convencional que, por circunstâncias não previstas no momento da formação do vínculo contratual, resulte, porventura, ao tempo da execução, mais gravosa, às vêzes até mesmo causa de empobrecimento e ruína para o devedor, na proporção, também imprevista, do aumento de vantagens para o credor.

São circunstâncias estas que justificam, como assinala Ripert, "uma série de leis modernas que atingem gravemente a fôrça obrígatória do contrato".

A doutrina da revisão vem já consagrada nos Códigos mais recentes, como o Italiano e outros, não em caráter de emergência ou provisório, mas como norma permanente para eventualidades como as ora expostas, o mesmo ocorrendo com o projeto do Código Brasileiro das obrigações.
Conservação dos sistemas

E' fora de dúvida, porém, que em a nossa nova legislação relacionada com a teoria geral e sobretudo com a teoria particula das obrigaçóes, não se nos pode deparar nada que signifique, de modo algum, alteracão fundamental, rutura do sistema do direito dos contratos, transformação do instituto.

De resto, o princípio da autonomia da vontade, bem que basilar nas convenções, jamais se exprimiu, nem mesmo no regime individualista, como um princípio absoluto, ao servico incondicional da liberdade contratual, sem peias de qualquer ordem, ao sabor ùnicamente das conveniências pessoais, dos interêsses de tôda espécie das partes pactuantes.

Ao contrário, a êle sempre se sobrepôs o interêsse da ordem pública, representado em leis coativas, inalteráveis pela vontade dos contratantes, como as fundadas 'em razóes de ordem moral, nos bons costumes.

Do mesmo modo, nenhum outro instituto igualmente nada sofreu em seu conceito, natureza e fundamentos, ante os novos disciplinamentos legais.

Dêstes, realmente, nenhum resultou em desfalque, antes em ganho para aquêles, todos se exprimiram.

Ao direito de família apenas se incorporaram novos provimentos. Quanto ao direito das sucessões, não se alteraram as regras sôbre a liberdade de testar, a sucessão legítima e o conceito de herdeiros necessários. E, no tocante ao direito das coisas só se pode dizer que o abasteceram, com a criação de novas espécies em relacão a direitos reais sôbre coisas alheias e também a respeito da propriedade, com o acréscimo de novas normas de sua constituição e uso sôbre certos bens da natureza, suscetíveis de ocupação ou já em domínio dos particulares.

E se é verdade que, neste último sentido, a mencionada legislação envolve necessàriamente certas limitacões ao direito de propriedade, na exploração, por exemplo, das florestas, das minas, da caça e pesca, da indústria e de águas, não é, todavia, menos certo que em nada se alteraram, nem se enfraqueceram mais os caracteres do instituto, a modo de se prever a sua supressão gradativa do elenco dos direitos individuais.

As limitações que se compreendem nessas disciplinas, além de dizerem respeito a novas fontes de enriquecimento, não são mais do que a reafirmacão, concorde já com o Código Civil, de que o direito de propriedade, salvo em remota antiguidade, como lembra Ruggero, nunca fôra concebido anteriormente como poder absoluto e ilimitado, mas, ao contrário, sujeito a restrições, que lhe limitam a índole individualista em atenção à sua finalidade também social, tais como as restrições de ordem privada, decorrentes, 
por exemplo, da situação de vizinhança predial, e as de ordem pública, administrativa, militar, eleitoral e outras, tôdas envolvendo, em suma, a imposição do respeito aos princípios de solidariedade social e de ordem pública.

$\mathrm{O}$ que se conclui, pois, da abundante legislação posterior à codificação de nosso direito civil e do modo por que ela, por assim dizer, quase insensivelmente se ajeitou ao momento e ambiente brasileiro para os quais necessàriamente foi elaborada, é que a solução para os problemas por ela assim regulados, provisória ou definitivamente, em situação política ora normal, ora discricionária, ora de novo normalizada, dispensava a prevalência de regimens políticos, e sobretudo de ideologias extremistas de qualquer de seus matizes.

A qualquer forma de govêrno de um povo servido por civilização cristã, a decisão legislativa, com tanto que inspirada, como no caso, no exato conceito e na compreensão certa do bem público, de qualquer forma se adaptaria, tanto mais quanto nenhuma transformação essencial trouxe a qualquer das instituições já existentes.

Estas assim resistiram e continuam resistindo à crise que conturba o mundo, ainda mais que esta, sôbre a maioria daquelas, nenhuma influência poderia exercer.

Pois elas, em verdade, se conjugam na corporificação de um direito civil moderno, com as suas normas tècnicamente formuladas e codificadas, após apuradas, aprimoradas, modeladas, destiladas pelo espaço de tempo de vários decênios no crisol de pareceres e discussões parlamentares brilhantes e magistrais, entre homens de notável inteligência, de esmerada cultura, de constante contacto com a ciência jurídica e de acurada visão; profundamente compenetrados, como sempre oxalá acontecesse, de sua alta missão de legisladores; confortados pelo talento criador e o saber soberbo do imortal autor do projeto do Código e pelo gênio de Ruy Barbosa, o qual, em discursos memoráveis e em páginas de alcandorada opulência linguística, incansàvelmente recomendava rigoroso purismo de redação dos textos, a bem da fidelidade na expressão das normas, contra o risco de interpretacões injustas.

Foram, assim, coordenadas em um código moderno, ultimado e sancionado em pleno flagrante da primeira conflagração mundial, na qual, é interessante neste lance recordar, a fôrça do direito se debatia por salvar-se das arremetidas cruentas e brutais do pretendido direito da fôrça, que até às convenções internacionais chamava "farrapos de papel".

Não é um código a que se ajuste o apôdo de lei da burguesia, que de uma feita fôra lançado ao Código Napoleão. Nem se reduz a um símile com o código soviético, feito "para um partido sem antagonista, e para a classe dos obreiros e camponeses".
E' muito mais do que isto, porque é apenas a unidade orgânica de normas justas e essenciais, destinadas a disciplinar com igualdade as relações privadas de tôdas as classes sociais de uma comunidade de homens livres; livres da prepotência brutal de partidos exclusivos; livres de ideologias que cerceiam, com sanções violentas, até mesmo as mais nobres e inofensivas expansões do pensamento a elas desagradáveis na política, nas ciências e até nas artes; livres de místicas raciais odiosas e de imperialismos hegelianos odientos.

E' um código moderno na idade, hoje ainda com menos de quarenta anos, contando pouco mais de um decênio quando, por contingências resultantes das duas guerras, começou de receber a nova legislação; e moderno também na ciência que cristaliza para a atualidade.

A cátedra estrangeira mesma tem oferecido a respeito testemunhos insuspeitos e valiosíssimos no sentido de que êsse código com uma "notável precisão e clareza ao serviço de uma excelente técnica jurídica, consagra um direito de valor universal correspondente aos progressos da legislação e da doutrina de todos os povos civilizados". Asseveram isto no $1^{\circ}$ volume, editado em 1950, de seu tratado de Direito Comparado, os professores das Universidades: Pierre Arminjon, de Genebra e Lausanne, e Martim Wolff, de Berlim, com a colaboração magnífica do Barão Boris Nold, antigo professor da Universidade de Petrogrado e antigo presidente do Instituto de Direito Internacional.

As instituições brasileiras de direito civil, assim refundidas neste conjunto orgânico, nesse grande monumento jurídico de fama mundial crescente, que bem justifica imensa gratidão naciona ao esfôrço ingente e corajoso de seus imortais obreiros, com Clovi Bevilaqua na supremacia, estão destarte aparelhadas em sua cida dela, ainda mais quando acrescidas agora e em nada desvirtuadas pelo contingente de novas leis suplementares, para, em sua essência e fundamentos, resistir, talvez por gerações, como têm resistido até aqui, a crises que se repetem filosóficas demolidoras, que buscam expor o mundo às incertezas e perigos de uma nova ordem.

Os apregoados males $e$ angústias, adversidades e desequilíbrios morais e econômicos do momento, com reflexos no direito civil, não implicaram, para êste, necessidade alguma de qualquer revogação de fundo.

"As metamorfoses econômicas e sociais do direito civil de hoje", das quais fala Savatier, talvez se compreendam em relação ao Código Napoleão, pôsto em vigor há precisamente 150 anos, meio século mais antigo, pois, do que o pecisame comercial, já profundamente transformado, êste sim, em mais de um de seus sistemas, como, por exemplo, no direito cambiário, 
além de modificado em outros pontos por novas leis, inclusive ais motivadas também pela crise econômica decorrente das duas conflagrações.

Em relação ao direito civil, porém, para os fatos novos verificados, bastava o direito existente suprido de novas provisões fornecidas pela subsequente legislação, sem transformações ou metamorfoses.

Os fatos, por exemplo, de famílias materialmente desajustadas; a situação dos menores abandonados e dos psicopatas; a desenvoltura da ganância; a agiotagem desenfreada; os problemas da locação predial; as desordens econômicas influindo nos contratos, na agricultura, nas indústrias; o desenvolvimento industrial; a necessidade de proteção às nossas florestas e lavouras; a situação das terras sem dono; a exploração aperfeiçoada de nossa fauna terrestre e aquática; a conveniência da criação de outros direitos reais e os problemas de águas não exigiam senão essas novas medidas legislativas.

Se o direito "é a ciência das relações sociais, só possíveis dentro da realidade social, faz-se mister apenas uma regra de direito diante de um fato social novo".

As novas necessidades, de cuja existência antes nem se haja suspeitado, criando outras relaçóes jurídicas e sociais, só reclamam provimento novo, que supra os da lei anterior, sem necessidade de reformá-la com abalos nos sistemas existentes quando aquelas relações não resultem de radicais transformações sociais.

Meus caros afilhados. Surdo à linguagem desalentadora dos céticos e derrotistas que contrasta com as alegrias e promessas desta hora festiva, e com o meu pensar e os meus sentimentos de fé no futuro, eu, neste instante profundamente significativo para a vossa vida de bachareis, que amanhã se inicia, abalanço-me a afirmar-vos a crença segura em que não devemos recear o flagelo ameaçador, em que tanto se fala, da destruição de nossos valores morais e jurídicos, nem mesmo ante os descalabros e desregramentos do momento presente - campo propício, embora, à infiltração de doutrina a que são avessas a nossa índole cristã e a nossa educação.

Não há de ser nas filosofias pagãs e materialistas do século passado; não há de ser no positivismo de nenhum dos seus matizes, no racionalismo frio, nos extremismos do oriente ou do ocidente, em nenhuma das teorias aberrantes de tôda metafísica e dos postulados do direito natural, que se logrará encontrar remédio a êsses males e às incertezas de amanhã.

A defesa de nossas instituições e sua salvação do naufrágio só se podem basear nos fundamentos da civilização cristã.

Falseiam a verdade sôbre os prognósticos dos desajustamentos sociais os pregoeiros, assustadiços sinceros ou pessimistas malicio- sos, que vêm tudo sombrio e tétrico, e sem remédio, e sem salvação.

Não há sucumbir o jurista ante tais prenúncios de rutura irremediável da ordem jurídica.

$\mathrm{O}$ direito que, em sua função, é essencialmente oportuno, tudo afinal, e como sempre, oportunamente superará, no desempenho do seu papel, representado por seus eleitos, vindos dos domínios da cultura, quais evangelizadores, para predicar em defesa dos princípios essenciais à ordem social e jurídica, preservar as instituições, propugnar pelo bem comum.

Os vagos e tristes e às vêzes tendenciosamente propalados presságios, aliás repetidos em tantos lances da história política, social e econômica da humanidade; esses maus presságios de desintegração geral dos naturais elos de concórdia entre os homens, as classes e as nações, dos sentimentos de solidariedade e de humanidade e do respeito a todos os valores que são atributos da personalidade humana - têm de se desvanecer e confundir-se e estacar ante uma fôrça poderosa, nem em todos os seres humanos adormecida ou negada, mas, ao contrário, de uma forma ou de outra, engastada na consciência e no coração da humanidade quase tôda inteira: é a força moral, de muitos e uníssonos sentidos, resultante da própria origem divina do sêr humano, feito à imagem e semelhança de Deus, e que se exprime no sentimento congênito de natural e imprescindivel solidariedade entre o homem e o gênero humano, em cujo seio aquêle, ligado a um grupo, tem necessàriamente de viver; e na soma de virtudes que se encastelam na devoção ao direito justo e na fé, isto é, na presença de Deus nas consciências, removendo montanhas de obstáculos opostos aos imperativos do harmonioso convívio social.

Aos vatícinios de calamidade mundial envolvidos nas amea ças de desintegração do átomo com objetivos bélicos, Einstein acode proclamando que sòmente com energias morais que lhe engrandecem a existência poderá o homem triunfar sôbre a investida de infortúnios que vêm ameaçando a civilização.

O gênio do mal não poderá prevalecer sôbre o gênio tutelar do bem.

As consciências presenciadas por Deus hão de vencer, afinal, aquelas acaso conturbadas pelos assaltos demoníacos da perver são.

A concepção absurda, utilitária e materialista de Hobbes que via no homem o lobo do homem e na monstruosidade do Leviathan do Estado totalitário, dotado de vontade soberana e absoluta para ditar tôda a lei, tôda a justiça e tôda a moral, a única fonte geradora da paz social - contrasta com a filosofia profundamente humana de Ralph Waldo Emerson, a quem numa exaltação de idealismo e de ternura pelo próximo, aprouve exclamar, 
mais de um século depois daquêle, que "a humanidade tem muito mais bondade do que se diz, pois apesar de todo o egoismo que gela o mundo como os ventos frígidos e bravios do Norte, tôda a família humana vive banhada em um elemento de amor diáfano como o éter".

Ao pesadelo daquela espécie de ceticismo desesperado e cruel do filósofo inglês, eu prefiro êste belo sonho, menos de filósofo do que de poeta, do excelso americano de Boston; e prefiro-o, no anseio de infiltrá-lo entre as luminosas esperanças que hoje vos conduzem desta casa, meus jovens colegas, para as lutas da vida em busca da fidelidade completa, no convívio de uma pátria cada vez mais engrandecida com a vossa ajuda e no seio de uma humanidade de dias mais felizes e cada vez mais fecundos.

Ao sairdes daqui, pela vida em fora, não vos abatam nunca os maus agouros sôbre a vida de nossas instituições.

Combatei em honra delas o bom combate, guiados sempre pelo exato sentido do lema que escolhestes e segundo o qual "mais glorioso do que pelas armas é vencer pela justiça".

E' essencial, não há dúvida, a concorrência simultânea, a conjugação, lado a lado, dos dois elementos - direito e fôrça.

Apoiado nesta é que aquêle cumprirá o seu destino, rumo à suprema fidelidade, que é o bem estar social.

Mas, se, desprotegido pela fôrça ou separado dela, o direito é, em regra, uma quimera - a fôrça, quando usada, não em defesa do direito e sim de interêsses aberrantes dêste, é uma inversão criminosa de valores; é um atentado; é, enfim, a violência.

A fôrça, como elemento integrante do direito, é exatamente a defesa dêste contra a violência.

Adulterando o papel da fôrça protetora do direito, num cerceamento de sua finalidade social, a violência ordinàriamente in quieta, sobressalta, quando não desorganiza, infelicita a sociedade e desvia os povos do curso normal de seus alevantados destinos.

A fôrça que serve e integra o direito, é um valor que o iguala o poder material da fôrça divorciada do direito é uma desgraça para a coletividade.

Sem a fôrça que lhe é inerente, o direito não funciona; a violência, porém, cala-o, emudece-o, imobiliza-o.

Daí, o infortúnio para a comunidade, que, diante disso, ou se inflama no inferno da anarquia, ou se algema na tirania, ou asfixia-se nas ondas impetuosas da prepotência, como aquelas outrora incriminadas na fala lapidar de Mont'Alverne. Em ambos êstes extremos perdem os cidadãos o grande bem da liberdade e muitos, possivelmente, o supremo bem da vida, que é a própria vida.

Se exercerdes um dia as prerrogativas de autoridade pública, sobretudo nas governanças, lembrai-vos de que entre elas se salienta a de exercitar a fôrça para o império do direito.

cia, que desvirtua a missão porém, contra as tentaçóes da violêneficiente e mais a másáo da autoridade, certos de que é mais sôbre os homens e purálico que se desempenha do que impondo-lo para os homens, governando-lhes os corações,

Entre as vicissitudes inevitá mente a autoridade pela violência. invariàvelmente, o melhor inevitaveis da vida, conforte-vos sempre,

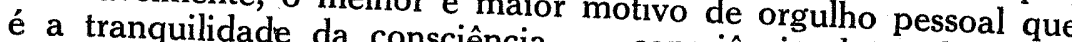
praticado o bem porciência de só haverdes proticado o bem, por atos de justiça e até mesmo de carider podendo sempre agradecer a Deus o nunca haverdes de caridade, ter injustiças e nem ato algum contrário haverdes sabido comedos homens e do evangelho. contrário aos mandamentos da lei Ao receberde 0 di

rejar nas lutas da vida, daqui com que a seguir entrareis a moupara oferecer-vos a minha derrai desta tribuna, aonde me erguestes de uma vida saúda o ra derradeira aula, o plúmbeo entardece vens que dão o último passo acade rosicler da aurora de 64 vidas joprimeiros da marcha profissio academico nesta casa, para ensaiar os os sorrisos de simpatia fofional, desertando êstes bancos por entre rançosos de uma hatia dos ex-colegas que aqui ainda ficam, espezíveis e afetivos dos que vos a esta para êles, e os regozijos indi. conchego do lar, que ús sáo caros no circulo social e no doce rande trido em festa, por motivo que é durne a um duradouro como a eternidade, ilimitado como onde se distingue, envolver em comovidas expressões de temo o infinito, para vos so ternura e santa alegria, Que as vossas lum a metamorfose triunfal nos almejados louros de cada jornada por outros, os mais palpite nobres ideais - eis, de mim para vós 